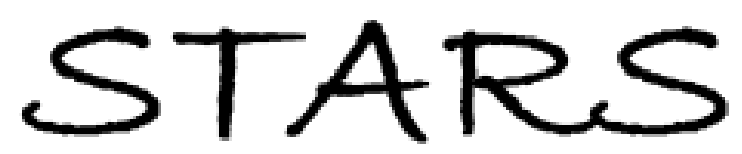

University of Central Florida

STARS

Faculty Scholarship and Creative Works

7-1-2020

\title{
Customer Experience in Tourism: A Review of Definitions, Components, and Measurements
}

\author{
Maksim Godovykh \\ University of Central Florida, maksim.godovykh@ucf.edu
}

Asli D. A. Tasci

University of Central Florida, asli.tasci@ucf.edu

Part of the Hospitality Administration and Management Commons, Marketing Commons, and the Tourism and Travel Commons

Find similar works at: https://stars.library.ucf.edu/ucfscholar

University of Central Florida Libraries http://library.ucf.edu

This Paper is brought to you for free and open access by STARS. It has been accepted for inclusion in Faculty Scholarship and Creative Works by an authorized administrator of STARS. For more information, please contact STARS@ucf.edu.

\section{Original Citation}

Godovykh, M., \& Tasci, A.D.A. (2020). Customer experience in tourism: A review of definitions, components, and measurements. Tourism Management Perspectives, 35, 1-10. https://doi.org/10.1016/ j.tmp.2020.100694

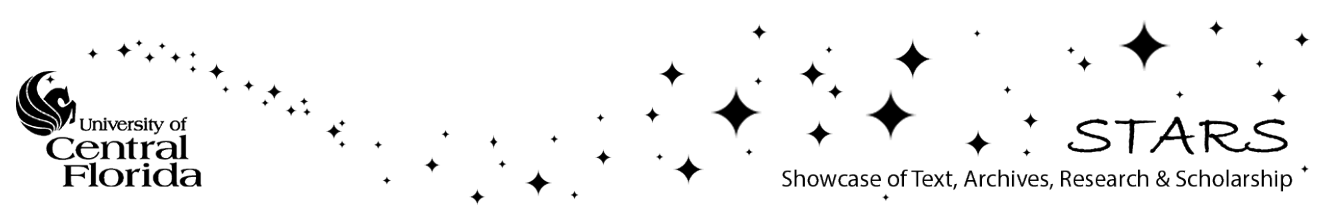




\title{
Customer experience in tourism: A review of definitions, components, and measurements
}

\begin{abstract}
Considered as a more competitive advantage than price, product, or quality, the concept of experience has received increasing attention in different disciplines. However, the pathway for handling experience has not been clearly set forth due to divergent conceptualizations and insufficient measures of customer experience. This study critically analyzes empirical and conceptual literature on experience, provides a holistic definition of experience, proposes an experience model with four main components (emotional, cognitive, sensorial, and conative), and suggests using a combination of several measures to capture the totality of tourism experience at pre-visit, onsite, and post-visit stages. These suggestions provide important implications for researchers and practitioners by offering new ways to explore customer interaction with tourist products, detect affective and sensory components leading to important consumption outcomes, investigate individual impacts of anticipation, onsite experience, and recall, as well as analyze effectiveness of destination marketing practices.
\end{abstract}

Keywords: experience, review, definition, components, scales

\section{$\underline{\text { To cite this article: }}$}

Godovykh, M., \& Tasci, A.D.A. (2020). Customer experience in tourism: A review of definitions, components, and measurements. Tourism Management Perspectives, 35, 1-10. https://doi.org/10.1016/j.tmp.2020.100694 


\section{Introduction}

Experience has received widespread attention in several fields. Pine and Gilmore (1999) defined the experience economy as the next stage of economic development following agrarian, industrial, and service economies, where the final business product is the experiences, a result of memorable events for customers. According to Shaw and Ivens (2002), 85\% of business management substantiates the belief that nowadays customer experience is the main competitive advantage rather than price, product, and quality. Csikszentmihalyi (1990) explained the importance of experiences in providing a deep sense of enjoyment that creates positive recollection.

However, capturing experience is a difficult task. Experience has several different meanings, and thus, has been defined in many different ways. Different conceptualizations of experience resulted in different components of customer experience such as educational, escapist, esthetic, entertainment (Pine \& Gilmore, 1999); emotional, informative, practice, transformation (Aho, 2001); and hedonism, refreshment, involvement, meaningfulness, knowledge, and novelty (Kim, Ritche, \& McCormik, 2012) to name a few. In order to fully understand customer experience in tourism, a comprehensive conceptualization is necessary. Other limitations of tourist experience studies source from the commonly used methodologies. The traditional methods applied in hospitality and tourism include investigating self-reported pleasure about visitors' past experience as a metric of their current feelings rather than the experience itself.

As the concept of experience gained popularity, recent years witnessed an increase in the efforts to define and measure this concept more accurately (e.g., Adhikari \& Bhattacharya, 2016; Hwang \& Seo, 2016; Packer \& Ballantyne, 2016; Palmer, 2010). Even though these reviews help to clarify the concept of experience, its components and its relationships with potential antecedents and consequences, they have not provided a holistic definition for the complex experience phenomenon, nor provided innovative methodologies to capture the illusive nature of consumer experience that changes at different points in time.

Thus, this critical review study is conducted to propose a comprehensive definition of visitor experience with four main components (emotional, cognitive, sensorial, and conative) and parsimonious model of tourist experience for pre-visit, onsite, and post-visit stages to be studied 
with a combination of techniques to capture the totality of tourism experience. Capturing the real nature of experience demands to measure it with psychological and psychophysiological approaches including traditional methods as well as innovative techniques such as day reconstruction, social media analytics, and psychophysiological research methods both in laboratory and field experiments. Only few researchers attempted using psychophysiological techniques in tourism literature (e.g., Kim \& Fesenmaier, 2015; Li et al., 2018), and there is still a lack of empirical support for applying the objective methodology of measuring tourist experience. Therefore, the paper aims to shift away from one-sided accent on any technique to use of a combination of psychophysiological techniques (e.g., self-report scales, experience sampling, electrodermal activity, lab experiments, etc.) with more traditional ones in measuring the totality of cognitive, affective, sensory, and conative experience components before, during, and after the trip.

Even though the focus of the current analysis is to clarify the definition of experience and suggest innovative measurement methods, the antecedents and outcomes of experience are also briefly summarized to highlight experience and its role in the relational network. The following section analyzes empirical and conceptual studies of experience, followed by conceptual and methodological suggestions. These suggestions provide researchers and practitioners helpful insights to better measure consumer experiences and design products for positive consumption outcomes.

\section{Definitions and components of experience}

Experience has been defined in many different consumption contexts. As can be seen in Table 1, many definitions are general without reflecting any component of experience specifically (e.g., Caru \& Cova, 2007; Mascarenhas, Kesavan, \& Bernacchi, 2006; Meyer \& Schwager, 2007; Prahalad \& Ramaswamy, 2004; Terblanche \& Boshoff, 2001). Such general definitions may be functional in stretching the concept across many different contexts; however, the lack of specific components also renders it to be easily diluted in the process. Other definitions focus on different components of experience. One of the earliest definitions by Holbrook and Hirschman (1982) refers to the hedonic nature of consumer experiences focusing on the sensory, emotive, and 
fantasy aspects of consumption. Berry and Carbone (2007) also focused on sensory and emotive aspects of experience.

\section{Table 1}

\section{Definitions of experience}

\begin{tabular}{|c|c|}
\hline Authors & Definitions \\
\hline Holbrook and Hirschman (1982) & "a steady flow of fantasies, feelings, and fun" (p.132) \\
\hline Csikszentmihalyi (1990) & $\begin{array}{l}\text { "the best moments usually occur when a person's body or mind is } \\
\text { stretched to its limits in a voluntary effort to accomplish something } \\
\text { difficult and worthwhile. Optimal experience is thus something we make } \\
\text { happen. " (p.3) }\end{array}$ \\
\hline Carbone and Haeckel (1994) & $\begin{array}{l}\text { "the aggregate and cumulative customer perception created during the } \\
\text { process of learning about, acquiring, using, maintaining, and } \\
\text { (sometimes) disposing of a product or service" (p. 18) }\end{array}$ \\
\hline Pine and Gilmore (1998) & $\begin{array}{l}\text { "experiences are inherently personal, existing only in the mind of an } \\
\text { individual who has been engaged on an emotional, physical, intellectual, } \\
\text { or even spiritual level" (p.99) }\end{array}$ \\
\hline O’Sullivan and Spangler (1998) & "events or feelings that occur prior, during, and after participation" (p. 23) \\
\hline Schmitt (1999) & $\begin{array}{l}\text { experiences “.... provide sensory, emotional, cognitive, behavioural and } \\
\text { relational values that replace functional values" (p. 26) }\end{array}$ \\
\hline Gupta and Vajic (2000) & $\begin{array}{l}\text { "an experience occurs when a customer has any sensation or knowledge } \\
\text { acquisition resulting from some level of interaction with different } \\
\text { elements of a context created by the service provider" (p. } 34)\end{array}$ \\
\hline Terblanche and Boshoff (2001) & $\begin{array}{l}\text { "all the elements that encourage or inhibit customers during their contact } \\
\text { with a retailer" (p.35) }\end{array}$ \\
\hline Shaw and Ivens (2002) & $\begin{array}{l}\text { "a blend of an organization's physical performance, the senses stimulated } \\
\text { and emotions evoked, each intuitively measured against customer } \\
\text { experience across all moments of contact" (p.6). }\end{array}$ \\
\hline Prahalad and Ramaswamy (2004) & $\begin{array}{l}\text { "creating an experience environment in which consumers can have active } \\
\text { dialogue and co-construct personalized experiences" (p. 8) }\end{array}$ \\
\hline $\begin{array}{l}\text { Mascarenhas, Kesavan, and } \\
\text { Bernacchi (2006) }\end{array}$ & $\begin{array}{l}\text { "a totally positive, engaging, enduring, and socially fulfilling physical and } \\
\text { emotional customer experience across all major levels of one's } \\
\text { consumption chain and one that is brought about by a distinct market } \\
\text { offering that calls for active interaction between consumers and providers" } \\
\text { (p. 399). }\end{array}$ \\
\hline Berry and Carbone (2007) & $\begin{array}{l}\text { "customers consciously and unconsciously filter a barrage of clues, in the } \\
\text { form of experiences, and organize them into sets of impressions-some } \\
\text { rational and others more emotional" (p.27) }\end{array}$ \\
\hline Caru and Cova (2007) & $\begin{array}{l}\text { "subjective occurrence that people go through pursuing a process of being } \\
\text { immersed in an experiential context" (p.35) }\end{array}$ \\
\hline Meyer and Schwager (2007) & $\begin{array}{l}\text { "the internal and subjective response customers have to any direct or } \\
\text { indirect contact with a company" (p.2) }\end{array}$ \\
\hline
\end{tabular}




\begin{tabular}{|c|c|}
\hline Authors & Definitions \\
\hline Getz (2007) & $\begin{array}{l}\text { "How people describe experiences as they occur, and talk about them } \\
\text { afterwards, remains in large part a mystery and therefore must be } \\
\text { considerable interest to event researchers and producers" (p. 171) }\end{array}$ \\
\hline Gentile, Spiller, and Noci, 2007 & $\begin{array}{l}\text { "The customer experience originates from a set of interactions between a } \\
\text { customer and a product, a company, or part of its organization, which } \\
\text { provoke a reaction" (p. 397) }\end{array}$ \\
\hline Larsen (2007) & $\begin{array}{l}\text { "A tourist experience is a past personal travel-related event strong enough } \\
\text { to have entered long-term memory" (p. 15) }\end{array}$ \\
\hline $\begin{array}{l}\text { Brakus, Schmitt, and Zarantonello } \\
\text { (2009) }\end{array}$ & $\begin{array}{l}\text { "subjective, internal consumer responses (sensations, feelings, and } \\
\text { cognitions) and behavioral responses evoked by brand-related stimuli that } \\
\text { are part of a brand's design and identity, packaging, communications, and } \\
\text { environments" (p.53) }\end{array}$ \\
\hline Palmer (2010) & $\begin{array}{l}\text { "on the one hand, experience is a learned outcome that is associated with } \\
\text { predictable behaviours, whereas on the other it has come to be associated } \\
\text { with processes whose novelty may result in unpredictable response by } \\
\text { consumers" (p.197) }\end{array}$ \\
\hline Bagdare and Jain (2013) & $\begin{array}{l}\text { "the sum total of cognitive, emotional, sensorial, and behavioural } \\
\text { responses produced during the entire buying process, involving an } \\
\text { integrated series of interaction with people, objects, processes and } \\
\text { environment in retailing" (p.792) }\end{array}$ \\
\hline Bonaiuto et al. (2016) & $\begin{array}{l}\text { "optimal experience... depicts the psychological mental state of a person } \\
\text { who is immersed in an activity with energized concentration, optimal } \\
\text { enjoyment, full involvement, and intrinsic interests, and who is usually } \\
\text { focused, motivated, positive, energized, and aligned with the task at hand" } \\
\text { (p.2) }\end{array}$ \\
\hline
\end{tabular}

On the other hand, Csikszentmihalyi (1990) included both the hedonic nature of experience with enjoyment and its cognitive nature terms of positive recollection. Gupta and Vajic's (2000) definition juxtaposed the hedonic and cognitive nature of experience by conceptualizing it as an outcome of a sensation of knowledge. The definition by Carbone and Haeckel (1994) is almost a complete shift from hedonic to cognitive nature of experiences by focusing on perception and learning during different phases of product use. Similarly, Larsen (2007) conceptualized experience by focusing on the strength of memory.

A few researchers conceptualized experience more holistically. The emergence of experience economy paradigm has widened the perspective on consumer experiences. O'Sullivan and Spangler (1998) outlined three types of actors in experience economy: infusers, or companies who produce their goods; enhancers, or service providers providing experiences to increase the levels of customer satisfaction; and experience makers, providing experiences as the main 
outcome of their activity. Pine and Gilmore (1999) introduced the experience economy as the next stage of economic development following agrarian, industrial, and service economies and describe the final business product as experiences as a result of memorable events for customers. With this new paradigm, Pine and Gilmore (1999) conceptualized experience by reflecting on internal responses resulting from emotional, physical, intellectual, and spiritual levels of consumer engagement. A few definitions reflect this holistic nature of experience by providing specific components. In the event context, Getz (2007) described different uses of the experience concept in terms of cognition, consciousness, affect, feelings, knowledge, and skills as well as different meanings of the verb "to experience" by describing happenings, emotions, feelings, and changes. Thus, he suggested a tri-component experience construct, where the conative component describes the actual behavior of people, the cognitive component represents people's understanding, memory, and evaluation of their experiences, while the affective component includes emotions and feelings related to experiences. Each component has its own distinctive nature, and therefore, might be achieved in different ways.

Recent studies also provided such holistic definitions (e.g., Brakus, Schmitt, \& Zarantonello, 2009; Palmer, 2010; Bagdare \& Jain, 2013). Bagdare and Jain's (2013) definition not only includes cognitive, emotional, sensorial, and behavioral components of experience, but also people, objects, and processes as the sources of such experiences in the environment. This definition is not only general enough for stretching into different consumption contexts, but also specific enough to maintain the integrity of the concept. Palmer's definition distinguishes between the verbal meanings of experience as a verb versus as a noun. His definition of experience as a noun reflects the cognitive, conative, and affective nature of experience.

Similar to definitions, several different components of experience have been provided in different consumption contexts (Table 2). In one of the early conceptualizations of experience in the general tourism context, Cohen (1979) proposed a typology of tourism experiences, including recreational, diversionary, experiential, experimental, and existential modes. In the general leisure context, Unger and Kernan (1983) explored five components of leisure experiences: arousal, spontaneity, involvement, mastery, and freedom. In the general consumption context, Hirschman (1984) asserted that there are only three stages of experience seeking: cognitive, sensation, and novelty. Later, Mannell and Kleiber (1997) presented the concept of "immediate 
conscious experience", which is related to the real-time behavior of the customers; they outlined the main components of conscious experience to be moods, emotions, feelings, involvement, sense of control, and sense of freedom.

\section{Table 2}

Components of experience

\begin{tabular}{|c|c|c|}
\hline Authors & Context & Components \\
\hline Cohen (1979) & General tourism & $\begin{array}{l}\text { Recreational mode, diversionary mode, experiential mode, } \\
\text { experimental mode, existential mode }\end{array}$ \\
\hline Unger and Kernan (1983) & Leisure & $\begin{array}{l}\text { Intrinsic satisfaction, perceived freedom, involvement, } \\
\text { arousal, mastery, spontaneity }\end{array}$ \\
\hline Hirschman (1984) & $\begin{array}{l}\text { General consumer } \\
\text { behavior }\end{array}$ & Cognitive, sensation, novelty \\
\hline Mannell and Kleiber (1997) & Leisure & $\begin{array}{l}\text { Moods, emotions, feelings, involvement, sense of control, } \\
\text { sense of freedom }\end{array}$ \\
\hline Pine \& Gilmore (1999) & General Business & Educational, escapist, esthetic, entertainment \\
\hline Schmitt (1999) & General marketing & Sense, feel, think, act, relate \\
\hline Holbrook (2000) & $\begin{array}{l}\text { General consumer } \\
\text { behavior }\end{array}$ & Entertainment, experience, exhibition, evangelizing \\
\hline Aho (2001) & General tourism & Emotional, informative, practice, transformation \\
\hline $\begin{array}{l}\text { Jennings and Nickerson } \\
(2006)\end{array}$ & General tourism & Traveler, product or destination, local population, \\
\hline Getz (2007) & Planned events & Conative, cognitive, affective \\
\hline $\begin{array}{l}\text { Gentile, Spiller, and Noci } \\
\text { (2007) }\end{array}$ & Product brands & Rational, emotional, sensorial, physical, spiritual \\
\hline Meyer and Schwager (2007) & General business & Cognitive, affective, emotional, social, physical \\
\hline $\begin{array}{l}\text { Brakus, Schmitt, and } \\
\text { Zarantonello (2009) }\end{array}$ & Brands & Sensory, affective, intellectual, behavioral \\
\hline Verhoef et al. (2009) & $\begin{array}{l}\text { General } \\
\text { management }\end{array}$ & Social, physical, emotional \\
\hline \multirow[t]{2}{*}{ Cutler and Carmichael (2010) } & General tourism & $\begin{array}{l}\text { Influential realm: physical aspects and product/service } \\
\text { aspects }\end{array}$ \\
\hline & & $\begin{array}{l}\text { Personal realm: knowledge, memories, perceptions, } \\
\text { emotions, and self-identity }\end{array}$ \\
\hline Palmer (2010) & $\begin{array}{l}\text { General consumer } \\
\text { behavior }\end{array}$ & Involvement, emotions, interpersonal relationships \\
\hline $\begin{array}{l}\text { Kim, Ritche, and McCormik } \\
\text { (2012) }\end{array}$ & Tourist memories & $\begin{array}{l}\text { Hedonism, refreshment, local culture, meaningfulness, } \\
\text { knowledge, involvement, novelty }\end{array}$ \\
\hline
\end{tabular}




\begin{tabular}{lll}
\hline Authors & Context & Components \\
\hline Hosany, Prayag, Deesilatham, & Destination & Joy, love, positive surprise \\
Senija, Causevic, and Odeh & & \\
(2015) & \\
\hline
\end{tabular}

Within the experience economy paradigm, Pine and Gilmore (1999) proposed four spheres of consumer experience: educational, escapist, esthetic, and entertainment experiences, which are differentiated by customer involvement and activity level. Schmitt (1999) provided a practical Strategic Experience Modules (SEM) highlighting five experiential modules which can be used to create customer experience: 1) sense, which creates experience through sound, sight, touch, smell, and taste; 2) feel, or creating affective experiences including joy and pride; 3) think, which involves cognitive experiences; 4) act, by showing customers different ways of doing things; and 5) relate, which goes beyond individual feelings and fulfills a desire for self-improvement.

At the onset of the $21^{\text {st }}$ century, the components of experience started reflecting a more humancentered perspective rather than a firm-centered approach. Aho (2001) explained the main resources contributing to personal experiences, as a time for thinking, money, knowledge, approaching skills, attitudes, and social networks; he then suggested splitting experience content into emotional, informative, practical, and transformation experiences. Some researchers referred to specific feelings and emotions; for example, Hosany, Prayag, Deesilatham, Senija, Causevic, and Odeh (2015) included joy, love, and positive surprise as components of experience in destination context. Gentile, Spiller, and Noci (2007) conceptualized customer experience elements as sensorial, cognitive, emotional, lifestyle, pragmatic, and relational components. Kim, Ritche, and McCormik (2012) argued that the main components of tourist experience are knowledge, refreshment, hedonism, local culture, meaningfulness, involvement, and novelty. Gnoth and Matteucci (2014) suggested that the theory building in tourism research is limited by the inability to capture the real components of tourism experience and introduced the Tourism Experience Model (TEM) for different components of tourist experience: pure pleasure, rediscovery, existentially authentic exploration, and knowledge seeking. Recently Rahmani, Gnoth, and Mather (2019) provided a psycholinguistic view of emotional components of tourist experience by extracting them from tourists' experience blogs and described emotional 
experience in tourism as multi-component process, which include positive dimensions (anticipation, trust, joy, etc.) and negative ones (sadness, disgust, anger).

Figure 1 demonstrates the frequency of previously described components of customer experience based on the review of 19 studies in tourism, leisure, consumer behavior, and general management. The most frequently explained components of experience are affective, cognitive, conative, and sensorial. The affective component is reflected in terminology such as affect, affective, feel, feelings, emotions, emotional, emotional states, and mood in different studies (e.g., Holbrook \& Hirschman, 1982; Unger \& Kernan, 1983; Csikszentmihalyi, 1990; Mannel \& Kleiber, 1997; Schmitt, 1999, 2003; Holbrook, 2000; Aho, 2001; Getz, 2007; Gentile, Spiller, \& Noci, 2007; Brakus, Schmitt, \& Zarantonello, 2009; Verhoef et al., 2009; Cutler \& Carmichael, 2010; Palmer, 2010; Rose, Clark, Samouel, \& Hair, 2012; Bagdare \& Jain, 2013). The cognitive component is described by terms such as cognition, cognitive, thoughts, educational, think, informative, intellectual, rational, knowledge, and memories (e.g., Holbrook \& Hirschman, 1982, 1984; Csikszentmihalyi, 1990; Schmitt, 1999, 2003; Aho, 2001; Getz, 2007; Gentile, Spiller, \& Noci, 2007; Meyer \& Schwager, 2007; Brakus, Schmitt, \& Zarantonello, 2009; Verhoef et al., 2009; Cutler \& Carmichael, 2010). The conative component is reflected in terms such as conative, behavior, behavioral, involvement, act, and practice (e.g., Aho, 2001; Brakus, Schmitt, \& Zarantonello, 2009; Getz, 2007; Holbrook \& Hirschman, 1982; Kim, Ritchie, \& McCormik, 2012; Mannell \& Kleiber, 1997; Palmer, 2010; Shmitt, 1999; Unger \& Kernan, 1983). The sensorial component is manifested in terms such as sense, sensory, sensation, and sensorial (Hirschman, 1984; Csikszentmihalyi, 1990; Shmitt, 1999, 2003; Gentile, Spiller, \& Noci, 2007, Brakus, Schmitt, \& Zarantonello, 2009). These components reflect a structure of experience with four dimensions: cognitive, affective, sensorial, and conative. 


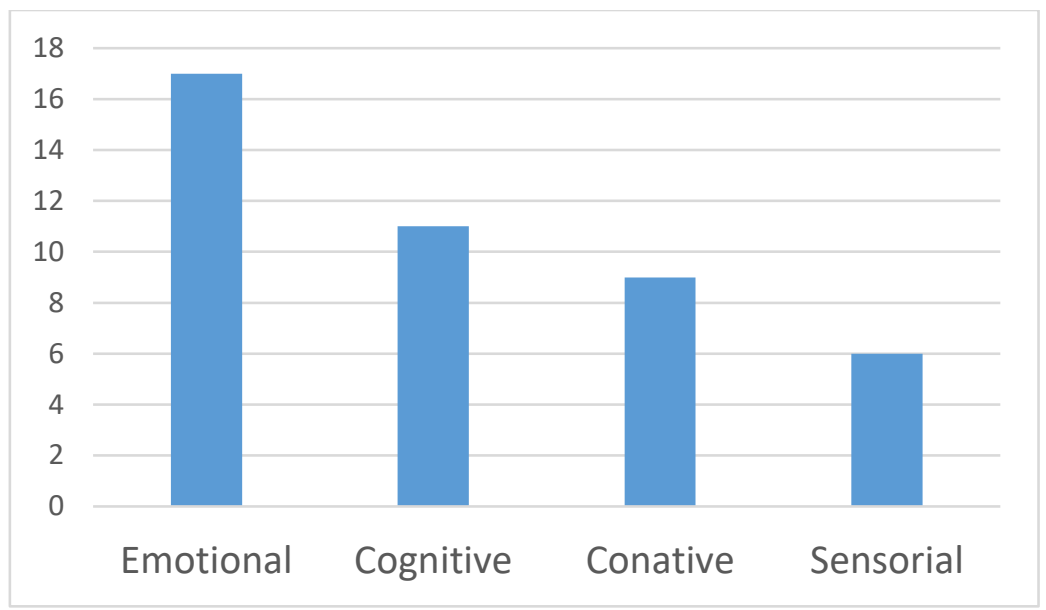

Figure 1. Components of customer experience (authors' own synthesis)

Even though experiential consumption switched the focus from cognition to emotions and sensation, emotions and sensations are often intertwined with thoughts and actions. Therefore, a comprehensive definition of experience and its components cannot be devoid of these critical components. Brakus, Schmitt, and Zarantonello's (2009) and Bagdare and Jain's (2013) definitions include all these components; however, they lack in clarifying the different phases of consumption. The experience starts with the arousal of the need for a product or service, need for vacation in tourism, leading to dreaming, motivation, information search, decision, purchase, planning, anticipation, visiting, remembering, and potentially planning to repurchase. Different steps in this process arouse different cognitive, affective and conative responses. In addition, this process has different levels of significance for different purchase situations. For significant experiences such as a vacation in a tourism context, all steps have contributions to the holistic experience as a visitor interacts with the products, services, suppliers, service providers, other consumers, technologies, and virtual realities in different steps.

A few literature reviews recently have reflected on these issues in definitions and components of experience and further clarified the concept of experience. For example, Palmer (2010) conducted a detailed semantic analysis of experience starting with dictionary definitions of the word as a noun and a verb as along with those definitions provided by the experience researchers. He then provided a framework of customer experience starting with static stimuli, brand relationships, and interpersonal relationships, which are integrated by consumers' dynamic processing of all cues and relationships rendered through emotional influences and perceptual 
distortions leading to an attitude. However, Palmer (2010) did not provide a clear definition of experience with indications of components and dimensions to guide future research on experience. More recently, Hwang and Seo (2016) conducted a critical review of experience research where they analyzed the meaning and components of experience and how they have been measured. Their analyses of the literature revealed that the current research is mostly conceptual; thus they called for more theory-driven empirical research in tourism and hospitality. They suggested future research to integrate different concepts into experience theory including "total customer experience, transcendent experience, transformational experience, authentic experience and the co-creation of experience" (Hwang \& Seo, 2016, p. 2218).

In the same year, Adhikari and Bhattacharya (2016) analyzed the general business, tourism and hospitality literature. They analyzed the definitions of experience from prospective, experience as an expected engagement or interaction, and reflective perspective, experience customer experience during or after the engagement or interaction. They discussed the formation of customer experience with cognitive and affective components and from co-creation perspectives. They also analyzed customer experience with internal and external experience consumption. In addition, they identified the effects or outcomes of customer experience as well as moderators springing from customer characteristics, group characteristics, and prior experiences. Even though in their detailed analysis of literature they acknowledged the sequential and changing nature of experience, in the end, they provided a rather static definition of experience: "customer experience is a combination of cognitive and affective components, the positive representation of which has a positive impact on customers' future experiences” (p. 313).

Another literature review in 2016 was conducted by Packer and Ballantyne (2016) in tourism, leisure, museum and visitor studies, in an effort to develop a multifaceted model of experience. They acknowledged the diverse meanings and definitions of experience as a hindrance to research and theoretical development of experience: "it is hoped that a shared vocabulary to describe and study the visitor experience may start to emerge. Without this common understanding, questions of semantics may become obstacles to further progress in this area" (p. 130). In arguing if visitor experiences subjective and internal or objective and external, they claimed that the "visitor experience is not a purely psychological phenomenon, but includes 'the activities, physical surroundings, service providers, other customers, companions, and other 
elements they engage with"' (p. 130-131). However, those factors external to the customer are more of stimuli, or antecedents, leading to experience rather than the experience itself.

Referring to the changing nature of experience, or experience as a transitory phenomenon (Volo, 2009), Packer and Ballantyne (2016) discussed the contribution of experience at different stages to the total consumption experience inclusive of anticipated and remembered portions of the experience (Falk \& Dierking, 2013). They referred to Dewey's (1963) principle of continuity (p. 35): "Every experience enacted and undergone modifies the one who acts and undergoes, while this modification affects the quality of subsequent experiences" and concluded that the boundaries of experience need to be clearly defined if it is referring to a single product or service in one point in time or if it is referring to the total experience from anticipation to remembering.

Packer and Ballantyne (2016) reflected on the spectrum of experience from mundane, commonplace, ordinary to peak, epiphanic, remarkable, transformative, or extraordinary (p. 132). Based on these premises, they defined visitor experiences happening outside of the everyday realm, they concluded that visitor experiences should be different "from the everyday flow of consciousness, either by its emotional intensity, or its framing in time and space" ( $p$. 133). Thus they defined visitor experiences as "an individual's immediate or ongoing, subjective and personal response to an activity, setting or event outside of their usual environment" (p.133) and reiterated its characteristics subjective and internal, responsive to external stimuli, bounded in space and time and significant for the visitor. Even though this definition captures the changing nature of experience, it fails to reflect multi-faceted experience components.

Packer and Ballantyne (2016) also provide a conceptual scheme of visitor experience as internal responses (thoughts and feelings) aroused by physical and social stimuli in environments, events, and activities filtered through visitor characteristics (previous experiences, interests, expectations, and motivations), eventually leading to visitor interpretations, narratives, and transformations, and ultimately to take away impressions (memories, stories, and insights). This framework includes cognition and affect but lacks sensory and conation components of experience. The authors also provide a diamond-shaped 10-facet visitor experience structure with physical, sensory, emotional, cognitive, and hedonistic experiences as the parts of the crown and restorative, introspective, transformative, spiritual, and relational experiences as the parts of the pavilion. They suggested that this model can be used to analyze the intensity and content of 
visitor experiences at for different consumers in different contexts, and then called for future research to investigate "whether the ten facets should all be considered to encapsulate both positive and negative responses (as if they were opposite ends of a continuum) or whether negative responses should be considered as separate facets" (p. 136). As attractive as this shape looks, it implies dual relationships between physical and restorative experiences, sensory and introspective experiences, cognitive and transformative experiences, emotional and spiritual experiences, and hedonistic and relational experiences. Physical sensory, cognitive, emotional and hedonistic experiences can be restorative, introspective, transformative, spiritual or relational rather than only one of them. Besides being limited in interrelations, this model seems to combine the components of experience with the outcomes. Since the authors did not clarify the relationships of these 10 experiences, the model does not seem to be measurable either. Furthermore, even though it reflects the potential multifaceted nature of experience, it diverges from scientific parsimony since these 10 different experiences complicate the concept and its relationships, rendering it rather unpractical. A complete definition of experience requires an understanding of its antecedents and outcomes in order to retain its conceptual integrity by differentiating it from its components, antecedents and outcomes.

\section{Antecedents and outcomes of experience}

Many antecedents related to consumers, brands and situational factors have been proposed to influence consumer behavior. One group of antecedents are related to consumer characteristics such as sociodemographics, psychographics, culture, prior experience (Adhikari \& Bhattacharya, 2016; Kim et al., 2012; Mak et al., 2012; Tse \& Crotts, 2005) familiarity, and past experience (Adhikari et al., 2013; Holbrook \& Hirschman, 1982; Hwang \& Lin, 2010; Kwun \& Oh, 2007; Ryu \& Jang, 2006), group characteristics (Finsterwalder \& Kuppelwieser, 2011; Kuppelwieser \& Finsterwalder, 2011; Wang, 1999). Some referred to consumer characteristics as antecedents (e.g., Hwang \& Seo, 2016) while others considered them as moderators (e.g., Adhikari \& Bhattacharya, 2016). Considering the nature of the study models, consumer characteristics can be considered either as antecedents or as moderators. In the current study, they are considered as antecedents. 
Another group of antecedents are related to the brand including price, promotion, quality, atmospherics, servicescape, socialscape, authenticity, online setting, employee characteristics and co-creation opportunities such as self-service settings (Adhikari \& Bhattacharya, 2016; Axelsen \& Swan, 2010; Gilmore \& Pine, 2002; Ha \& Jang, 2010; Hwang \& Seo, 2016; Ismail, 2011; Lee et al., 2010; Pearce \& Moscardo, 1986; Namkung \& Jang, 2007; North et al., 2003; Ryu \& Jang, 2006; Verhoef et al., 2009; Williams, 2006; Wijaya et al., 2013). Co-creation or coproduction of experience between customer and brand and other customers of the brand (Gentile et al., 2007; Kirpalany, 2011; Selstad, 2007; Verhoef et al., 2009) online experiences through information technology (Lan Luo \& Ratchford, 2008) have received attention from researchers. The third set of antecedents is related to situational factors in the consumption context (Hwang \& Seo, 2016) and macro-environmental factors such as the economy (Grewal et al., 2009).

Similar to antecedents, consumer experience is proposed to result in outcomes related to customers as well as those specific to brands. Specific brand-related outcomes of experience are listed as perception, loyalty, word-of-mouth, increased consumption, lower price sensitivity, brand trust, brand commitment, brand involvement, brand advocacy, satisfaction with brand, and purchase decision (Brakus et al., 2009; Gentile et al., 2007; Holbrook, 2006; Iglesias et al., 2011; Ismail et al., 2011; Oh, Fiore, \& Jeoung, 2007; Roth \& Menor, 2003; San Martin, Collado, \& Rodriguez del Bosque, 2013; Tsaur et al., 2007; Tynan \& McKechnie, 2009; Zhang, Agarwal, \& Lucas, 2011; Bigne, Andreu, \& Gnoth, 2005). Many of these concepts are the components of a composite construct of consumer/customer-based brand equity, which is also proposed to be affected by customer experiences (Ambler et al., 2002; O’Dell \& Billing, 2005; Rust, Zeithaml, $\&$ Lemon, 2001). Several outcomes have also been discussed related to customers. Experience is purported to result in emotional outcomes such as fun, enjoyment, nostalgia, fantasizing, entertainment, happiness (Holbrook, 2000; Holbrook \& Hirschman, 1982; Holbrook \& Schindler, 2003; Tynan \& McKechnie, 2009), conative outcomes such as learning (Holbrook \& Hirschman, 1982), cognitive outcomes such as knowledge and skills (Holbrook \& Hirschman, 1982; Poulsson \& Kale, 2004), satisfaction - as consumers' well-being as a result of consumption (Bolton \& Drew, 1991; Boulding, Kalra, Staelin, \& Zelthaml, 1993; Ooi, 2005; Yi \& Gong, 2009) value/utility (Adhikari \& Bhattacharya, 2016; Arora, 2012), motivation (Pearce \& Caltabiano, 1983) and transformation (Hwang \& Seo, 2016; Packer \& Ballantyne, 2016). 


\section{Holistic definition and relational network of experience}

Based on the above discussion of empirical studies and comprehensive literature reviews, a comprehensive yet parsimonious definition of experience is synthesized: Experience is the totality of cognitive, affective, sensory, and conative responses, on a spectrum of negative to positive, evoked by all stimuli encountered in pre, during, and post phases of consumption affected by situational and brand-related factors filtered through personal differences of consumers, eventually resulting in differential outcomes related to consumers and brands. The holistic nature of this definition resides in five aspects that have not been captured together in previous definitions: 1) it comprises four main components acknowledged by the majority of researchers: affect, cognition, sensory, and conation, as reflected in Figure 2; 2) it acknowledges the spectrum of negative to positive cognitive, affective, sensory, and conative responses; 3 ) it acknowledges pre, during, and post-consumption phases of experience; 3) it implies potential determinants of experience as brand-related, consumer-related and situational factors; and 4) it implies potential outcomes of experience related to brands and consumers. It should be noted that experience is a neutral concept, which can range from low to high levels in both positive and negative directions. Positive consumption situations may result in peak positive experiences while negative consumption situations may result in peak negative experiences.

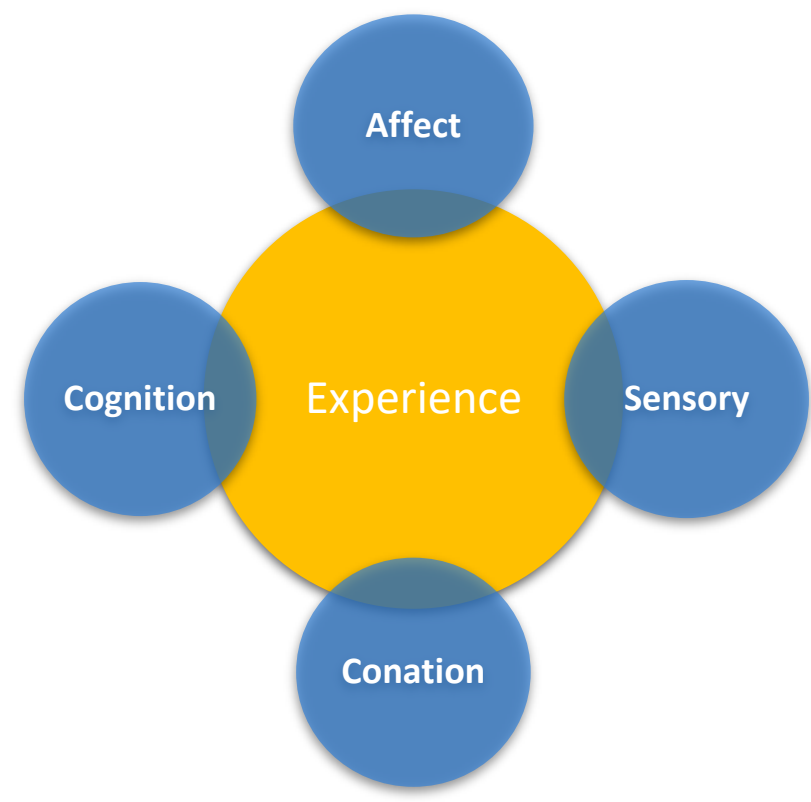


Figure 2. The main components of experience (authors' own conceptualization)

As also reflected in the relationship network of experience in Figure 3, four components of experience can take place in different stages of consumption, pre, during, and post-consumption, which are dynamic and changeable. Experience in all phases can be affected by several antecedents sourcing from brand-related stimuli, consumer-related factors filtering these stimuli, as well as situational factors such as consumption context and macro-environmental factors.

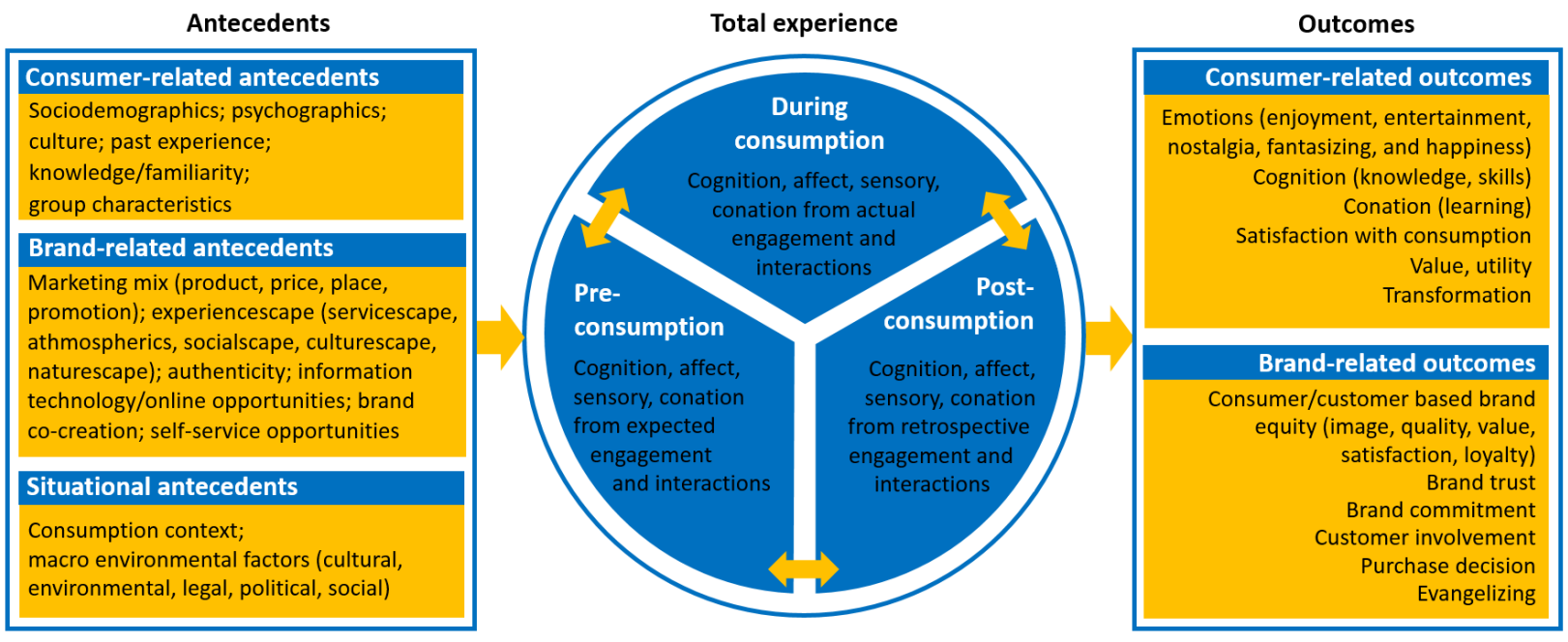

Figure 3. The sequential nature of pre-visit, onsite, and post-visit experiences, antecedents and outcomes (authors' own conceptualization)

Additional to those listed in the literature, some new antecedents can be added to experience relationship network. Even though price and promotion have been discussed in their relation to consumers' past experience (Adhikari \& Bhattacharya, 2016), all components of the marketing mix (product, price, promotion, and place) can be expected to influence experience. In addition, experienscape (inclusive of atmospherics, servicescape, socialscape, culturescape and naturescape as conceptualized by Pizam \& Tasci, 2019) is also an inherent antecedent of experience. Even though macroeconomic factors were acknowledged as antecedents of experience (Hwang \& Seo, 2016), environmental, technical, cultural, political, and social trends 
and issues can also affect experiences. Consumers' sustainability concerns, technological trends, political agenda, cultural and subcultural changes can have significant influences on consumer experience. The total experience from pre, during, and post experiences then result in several outcomes related to consumers' affect, cognition, and conation as well as brand-related outcomes such as satisfaction with the brand, brand loyalty, and the composite construct of consumer/customer-based brand equity. Measuring this comprehensive experience construct requires innovative techniques besides the traditional ones.

\section{Measuring experience}

Most customer experience research seems to fail to capture the totality of customer experience with its different components. Traditional methods mostly measure cognitive and conative experience components by investigating self-reported pleasure from past experience as a metric of customers' current feelings rather than the experience in totality. Several experience scales were inspired by Pine and Gilmore's (1999) four realms of experience: educational, escapist, esthetic, and entertainment, which are differentiated by the level of activity and customer involvement. As an example from the tourism and hospitality research, Ali, Hussain, and Ragavan (2014) classified experience in these four dimensions and developed the 16-item customer experience scale in the context of resort hotels. Another experience scale was initiated in a retail setting and incorporated other experience dimensions: joy, mood, leisure, and distinctive (Bagdare \& Jain, 2013). Klaus and Maklan (2013) introduced an alternative measure of customer experience, the customer experience quality (EXQ) scale, which consisted of 19 items and was validated across different services and service channels.

With a slightly differentiated term, memorable experience, Kim, Ritche, and McCormik (2012) suggested using the Memorable Tourism Experience scale (MES) with seven constructs: hedonism, refreshment, meaningfulness, local culture, knowledge, novelty, and involvement. However, their second-order model with affective, cognitive, and behavioral components as the latent variables demonstrated that affective and cognitive components shared common variances and that the MTE scale fits better using the first-order structure. Another study by Otto and Ritchie (1996) uses hedonics, peace of mind, involvement, and recognition to develop a tourism 
service experience scale, which was tested in different tourism settings, including hotels, airlines, and attractions. The most cited experience scale study by Brakus, Schmitt, and Zarantonello (2009) describes sensory, affective, intellectual, and behavioral components of brand experience and suggests measuring these components by using a 12-item brand experience scale. This scale was further replicated by Barnes, Mattsson, and Sorensen (2014) in a destination setting. However, applying the sensorial and affective scale items evoked by the design, identity, communication, packaging, and environment of the famous conventional brands (Apple, CocaCola, BMW, etc.) into the destination context causes several doubts. For instance, such survey questions as "the destination is interesting in a sensory way", or "destination gives me bodily experience" developed for the conventional product brand studies might be incomprehensible for tourists in the destination context.

Additionally, such self-reported scales pose several limitations. First, study results can be influenced by respondents' biases such as social desirability, resulting from people's desire to under-report socially undesirable activities in favor of more attractive ones (Ganster, Hennessey, \& Luthans, 1983). Second, people's responses can be biased by the availability heuristic as they tend to overestimate events that come to mind (Kahneman \& Tversky, 1979). Third, people's memories can also be influenced and reorganized by their knowledge and beliefs (Ross, 1989). Fourth, people's answers can be biased by their mood at the time of answering questions (Cantor \& Kihlstrom, 1987). Therefore, a comprehensive understanding of tourist experience requires research methods that allow measuring components of experience moment-by-moment as it unfolds.

Recent literature reviews and critical reviews shed some light on the difficulty of measuring experience; however, they have not offered innovative measurement methods or techniques. Neither Adhikari and Bhattacharya (2016) nor Packer and Ballantyne (2016) offered any new methodological insights to capture experience. After discussing the challenges of measuring consumer experience, Palmer (2010) acknowledged the difficulty of measuring nonlinearity of customer experience using any single method. He discussed in detail the changing, dynamic, and transitory nature of experience and thus the difficulties of measuring this elusive concept. Highlighting the challenges springing from situational factors, non-linearity of experience, and 
the difficulty of identifying the optimal experience level, he deemed the standard survey design inadequate, especially in measuring the changing nature of affective dimensions of experience.

Hwang and Seo (2016) also acknowledged the multidimensional sequential nature of experience and listed a number of measurement challenges including the variable definitions and components, changing nature of affective attitude, difficulty of measuring the experience itself, subjective and irrational emotional dimensions, the questionable validity in self-reported emotions, and situational and context-driven nature of experiences. Thus, they called for innovative approaches to the measurement of customer experiences and suggested using “experience sampling method, grid technique, netnography, and structured content analysis", as well as more of a cultural lens in studying customer experience (Hwang \& Seo, 2016, p. 2238).

The experience sampling method makes it possible to study people's subjective experience while interacting in natural settings by asking respondents to report on their feelings, behaviors, and thoughts on random occasions over time (Bolger \& Laurenceau, 2013). Several recent tourism studies investigated visitors' experiences during different activities by using the experience sampling method. For example, Jones, Hollenhorst, and Perna (2003) compared models of optimal experience of whitewater kayakers by applying the Experience Sampling Method. Birenboim, Reinau, Shoval, and Harder (2015) used experience sampling data collection technique to explore subjective experiences of zoo visitors and concluded that the quality of experiences varies in time and space. Borrie and Roggenbuck (2001) collected experience sampling data from Okefenokee National Wildlife Refuge visitors to analyze the nature of the wilderness experience and its temporal dimensions. Experience sampling could be useful in tourist experience studies since it helps to reveal impacts of a particular event by comparing responses before and after the experience; compare consumers' experience of events; and examine duration, magnitudes, and sequences of visitor emotional states (Csikszentmihalyi \& Larson, 2014). Nonetheless, the experience sampling method is also dependent on participants' self-reports and has several limitations related to self-report measures, which can be eliminated by applying more objective measures of tourist experience.

The majority of previous studies described the prevalence of affective components of visitor experience (Aho, 2001; Gentile et al., 2007; Meyer \& Schwager, 2007; Palmer, 2010). However, as was also acknowledged by Mauss and Robinson (2009), measuring emotions is one of the 
most difficult tasks, and both the existing methods and those newly introduced techniques fail to capture emotional states before, during, and after the visit. The emotional response starts from the appraisal of the situation and results in subjective experience, physiological reactions, and behavior, while there is a debate about the precedence of emotional reactions versus cognitive appraisals in the social and cognitive psychology literature (e.g. Parkinson \& Manstead, 1992). Consequently, different measurement techniques might be applied to investigate emotional responses as part of the customer experience.

Although emotions are traditionally measured retrospectively in tourism and hospitality research (e.g., Soodan, \& Pandey, 2016), there is an opportunity to measure them by applying the moment-based psychophysiological techniques, which reflect electrochemical changes in neurons, muscles, and gland cells (Stern, Ray, \& Quigley, 2001). Different emotions involve different patterns of activation of both branches of the human autonomic nervous system (sympathetic and parasympathetic), which can be useful in analyzing people's emotional states (Kreibig, 2010). The sympathetic system is associated with activation and mobilizing, while the parasympathetic system is related to relaxation and dampening. Arousal has been reported as the best way to reflect responses of the autonomic nervous system (Cacioppo, Berntson, Larsen, Poehlmann, \& Ito, 2000). Arousal can be measured by using electrodermal activity, electrocardiography, pupillometry, and some other techniques (Stern, Ray, \& Quigley, 2001). At the same time, different branches of autonomic nervous system activity can work independently or against each other (Bradley \& Lang, 2000), hence the second dimension of valence could be applied to reflect these differences (Russell \& Mehrabian, 1977). Valence can be measured by applying facial electromyography, electroencephalography and other methods. Several studies suggest that multiple measures of the autonomic nervous system may provide a better degree of autonomic specificity (Stern, Ray, \& Quigley, 2001). Psychophysiological responses are not controlled by people and can eliminate the limitations of self-report and behavioral measures (Larsen and Fredrickson, 1999). Moreover, psychophysiological recordings provide moment-bymoment values of respondents' emotional reactions (Wilhelm \& Grossman, 2010) and can be used before, during, and after the experience.

Some researchers also suggest measures to capture the sensory components of consumptions, which include hearing, seeing, tasting, smelling, and feeling (Holbrook \& Hirschman, 1982; 
Agapito, Valle, \& Mendes, 2014). Bech-Larsen and Nielsen (1999) applied elicitation interview techniques to compare different sensory attributes of a product. Gretzel and Fesenmaier (2010) introduced the Sensory Experience Elicitation Protocol (SEEP), which consists of open-ended questions to elicit sensory association networks in consumers' minds. They categorized tourists' sensory experiences in the Midwest United States to apply in destination marketing. Another example of sensory impressions research is the study by Agapito, Valle, and Mendes (2014), who applied survey questions related to five human senses (sight, smell, hearing, touch, smell) to analyze sensory tourist experiences of Southwest Portugal and segment visitor experiences into four sensory-informed themes: rural; nature-based; beach-related; and balanced experience. A number of researchers suggested using other methods of capturing people's sensory experiences (e.g., Dunn, 1997; Wendin, Allesen-Holm, \& Bredie, 2011; Hayes, 2015).

However, recent evidence suggests the mutual influence of emotional and sensory brain cortices. For example, Vuilleumier (2005) described the role of the amygdala in providing sensory signals, which influence the representation of emotions, while Sacco and Sacchetti (2010) explained the effects of sensory cortices on emotional responses. Hence, it seems possible that measuring the affective (feelings, emotions) component of experience could be similar to those for measuring the sensory component.

Each measurement technique has its advantages and limitations. In spite of evident advantages of self-report measures related to their simplicity, low-cost, and measuring multiple concepts in one setting (Paulhus \& Vazire, 2007), their limitations do not allow capturing unconscious, affective, and sensorial components of experience or the temporal changes in them (Poels \& Dewitte, 2006). The experience sampling method aimed at providing the temporal profile of experience is also influenced by self-report biases (Csikszentmihalyi \& Larson, 2014). Several psychophysiological techniques that could provide measures of affective and sensorial responses are also limited by susceptibility to stimuli, individual differences, and interpretation of results (Stern et al., 2001). Therefore, only applying a combination of several methods such as selfreport scales, experience sampling, laboratory experiments, and psychophysiological techniques could help to capture the totality of customer experience with its different components at previsit, on-site, and post-visit stages. 


\section{Conclusion}

This critical analysis of previous empirical and conceptual studies on experience showed that conceptualization and operationalization of customer experience require a deeper understanding of its components, antecedents, outcomes, and measurement methods. Experience has been previously defined in many different consumption contexts, and numerous components of experience have been provided in the past literature including educational, escapist, esthetic, entertainment (Pine \& Gilmore, 1999); emotional, informative, practice, transformation (Aho, 2001); hedonism, refreshment, knowledge, meaningfulness, involvement, and novelty (Kim, Ritche, \& McCormik, 2012), among others.

This study proposes a comprehensive but parsimonious definition of experience as the totality of cognitive, affective, sensory, and conative responses, on a spectrum of negative to positive, evoked by all stimuli encountered in pre, during, and post phases of consumption affected by situational and brand-related factors filtered through personal differences of consumers, eventually resulting in differential outcomes related to consumers and brands. This definition is particularly useful in explaining and measuring tourism and hospitality experiences as it describes the four major components of experience as reactions at pre-visit, on-site, and postvisit stages of the trip. Besides, measuring experience in tourism and hospitality consumption settings with all four components is critical due to the intangible and highly hedonistic nature of products. Furthermore, various sources of antecedents and outcomes of experiences are also vital in capturing tourism and hospitality experiences that are intertwined with many other factors. However, capturing tourism and hospitality experiences is not an easy endeavor due to the difficulties of capturing some components of experience. From a practical viewpoint, the four experience components (cognitive, affective, sensorial, and conative) offer tourism providers and destination marketers an opportunity to incorporate these dimensions into their products and services.

The existing experience scales seem to fail to capture the totality of customer experience with its different components. Even though most frequently mentioned components of experience in the literature are affective in nature, the most widely used measures applied in tourism and hospitality research are the traditional retrospective self-reported evaluation of the previous experience rather than the experience in totality. These measures do not capture the affective 
components of visitor experience because of social desirability, availability heuristics, memory biases, mood at the time of answering questions, unconscious nature of affective experiences, and temporal experience dimensions. Therefore, capturing the real nature of visitor experience demands to measure it with a combination of different approaches including traditional selfreport methods, elicitation interview techniques, experience sampling method, as well as psychophysiological techniques.

Applying a combination of several techniques (e.g., self-report scales, experience sampling, electrodermal activity, and lab experiments) offers important implications for tourism researchers and practitioners. First, the combination of several techniques allows continuously recording different components of tourist experience, exploring the profiles of customer interaction with the tourist products, including the peak moments as the most important determinants of the total experience. It will also help to reveal the accuracy and limitations of traditionally applied self-report scales of visitor experience. Second, using a combination of such measures would enable detecting affective and sensory components that tourists may not be aware of; these affective and sensory components may, indeed, be the precursors of important outcomes like well-being and transformation. Third, the combination of several measures helps to analyze the effectiveness of destination marketing practices by investigating experience responses during and after different advertisement scenarios. Forth, understanding the temporal profile of tourism experience allows analyzing individual effects of each temporal trip component, including anticipation, onsite experience, and recall, thus helping to design better tourism experiences for superior outcomes. 


\section{References}

Adhikari, A., \& Bhattacharya, S. (2016). Appraisal of literature on customer experience in tourism sector: review and framework. Current Issues in Tourism, 19(4), 296-321.

Adhikari, A., Basu, A., \& Raj, S. P. (2013). Pricing of experience products under consumer heterogeneity. International Journal of Hospitality Management, 33, 6-18.

Agapito, D., Valle, P., \& Mendes, J. (2014). The sensory dimension of tourist experiences: Capturing meaningful sensory-informed themes in Southwest Portugal. Tourism Management, 42, 224-237.

Aho, S. K. (2001). Towards a general theory of touristic experiences: Modelling experience process in tourism. Tourism Review, 56(3/4), 33-37.

Ali, F., Hussain, K., \& Ragavan, N. A. (2014). Memorable customer experience: Examining the effects of customers experience on memories and loyalty in Malaysian resort hotels. Procedia-Social and Behavioral Sciences, 144(1), 273-279.

Ambler, T., Bhattacharya, C. B., Edell, J., Keller, K. L., Lemon, K. N., \& Mittal, V. (2002). Relating brand and customer perspectives on marketing management. Journal of Service Research, 5(1), 13-25.

Arora, R. (2012). A mixed method approach to understanding the role of emotions and sensual delight in dining experience. Journal of Consumer Marketing, 29(5), 333-343.

Axelsen, M., \& Swan, T. (2010), Designing festival experiences to influence visitor perceptions: The case of a wine and food festival, Journal of Travel Research, 49(4), 436-450.

Bagdare, S., \& Jain, R. (2013). Measuring retail customer experience. International Journal of Retail \& Distribution Management, 41(10), 790-804.

Barnes, S. J., Mattsson, J., \& Sorensen, F. (2014). Destination brand experience and visitor behavior: Testing a scale in the tourism context. Annals of Tourism Research, 48, 121139.

Bech-Larsen, T., \& Nielsen, N. A. (1999). A comparison of five elicitation techniques for elicitation of attributes of low involvement products. Journal of Economic Psychology, 20(3), 315-341.

Berry, L. L., \& Carbone, L. P. (2007). Build loyalty through experience management. Quality Progress, 40(9), 26. 
Bigne, J. E., Andreu, L., \& Gnoth, J. (2005). The theme park experience: An analysis of pleasure, arousal and satisfaction. Tourism Management, 26(6), 833-844.

Birenboim, A., Reinau, K. H., Shoval, N., \& Harder, H. (2015). High-resolution measurement and analysis of visitor experiences in time and space: The case of Aalborg zoo in Denmark. The Professional Geographer, 67(4), 620-629.

Bolger, N., \& Laurenceau, J.P. (2013). Intensive longitudinal methods: An introduction to diary and experience sampling research. New York, NY: Guilford Press.

Bolton, R. N., \& Drew, J. H. (1991). A multistage model of customers' assessments of service quality and value. Journal of Consumer Research, 17(4), 375-384.

Bonaiuto, M., Mao, Y., Roberts, S., Psalti, A., Ariccio, S., Ganucci Cancellieri, U., \& Csikszentmihalyi, M. (2016). Optimal experience and personal growth: flow and the consolidation of place identity. Frontiers in Psychology, 7, 1-12.

Borrie, W. T., \& Roggenbuck, J. W. (2001). The dynamic, emergent, and multi-phasic nature of on-site wilderness experiences. Journal of Leisure Research, 33(2), 202-228.

Boulding, W., Kalra, A., Staelin, R., \& Zelthaml, V. A. (1993). A dynamic process model of service quality: From expectations to behavioral intentions. Journal of Marketing Research, 30(1), 7-27.

Bradley M. M., \& Lang P.J. (2000). Measuring emotion: Behavior, feeling, and physiology. In R.D. Lane \& L. Nadel (Eds.), Cognitive neuroscience of emotion (242-276). New York, NY: Oxford University Press.

Bradley, M. M., Greenwald, M. K., Petry M.C.,\& Lang, P. J. (1992). Remembering pictures: Pleasure and arousal in memory. Journal of Experimental Psychology: Learning, Memory, and Cognition, 18(2), 379-390.

Brakus, J. J., Schmitt, B. H., \& Zarantonello, L. (2009). Brand experience: what is it? How is it measured? Does it affect loyalty?. Journal of Marketing, 73(3), 52-68.

Cacioppo J.T., Berntson G.G., Larsen J.T., Poehlmann K.M., \& Ito T.A. (2000). The psychophysiology of emotion. In: M. Lewis, J.M. Haviland-Jones (Eds.) The handbook of emotion (173-191). New York, NY: Guildford Press.

Cacioppo, J. T., Berntson, G. G., Larsen, J. T., Poehlmann, K. M., \& Ito, T. A. (2000). The psychophysiology of emotion. Handbook of emotions, 2, 173-191. 
Camerer, C. F. (2011). Behavioral game theory: Experiments in strategic interaction. Princeton, NJ: Princeton University Press.

Cantor, N., \& Kihlstrom, J. F. (1987). Personality and social intelligence. Englewood Cliffs, NJ: Prentice-Hall.

Carbone, L. P., \& Haeckel, S. H. (1994). Engineering customer experiences. Marketing Management, 3(3), 8-19.

Cohen, E. (1979). A Phenomenology of Tourist Experiences. Sociology, 13(2), 179-201.

Cook, T. D., Campbell, D. T., \& Shadish, W. (2002). Experimental and quasi-experimental designs for generalized causal inference. Boston, MA: Houghton Mifflin.

Cowen, A. S., \& Keltner, D. (2017). Self-report captures 27 distinct categories of emotion bridged by continuous gradients. Proceedings of the National Academy of Sciences, 114(38), E7900-E7909.

Csikszentmihalyi, M. (1990). Flow: The psychology of optimal experience. New York, NY: Harper \& Row.

Csikszentmihalyi, M., \& Larson, R. (2014). Validity and reliability of the experience-sampling method. In M. Csikszentmihalyi (Ed.) Flow and the foundations of positive psychology (35-54). New York, NY: Springer.

Cutler, S. Q., \& Carmichael, B. A. (2010). The dimensions of the tourist experience. The tourism and leisure experience: Consumer and Managerial Perspectives, 44, 3-26.

Dewey, J. (1963). Experience and education. New York, NY: Macmillan.

Dunn, W. (1997). The impact of sensory processing abilities on the daily lives of young children and their families: A conceptual model. Infants and Young Children, 9(4), 23-35.

Falk, J. H., \& Dierking, L. D. (2013). The museum experience revisited. Walnut Creek, CA: Left Coast Press.

Finsterwalder, J., \& Kuppelwieser, V. G. (2011). Co-creation by engaging beyond oneself: The influence of task contribution on perceived customer-to-customer social interaction during a group service encounter. Journal of Strategic Marketing, 19(7), 607-618.

Ganster, D. C., Hennessey, H. W., \& Luthans, F. (1983). Social desirability response effects: Three alternative models. Academy of Management Journal, 26(2), 321-331. 
Gentile, C., Spiller, N., \& Noci, G. (2007). How to sustain the customer experience: An overview of experience components that co-create value with the customer. European Management Journal, 25(5), 395-410.

Getz, D. (2007). Event studies: theory, research and policy for planned events. Boston, MA: Butterworth-Heinemann.

Gilmore, J. H. \& Pine, B.J. (2002), "Differentiating hospitality operations via experiences: why selling services is not enough", The Cornell Hotel and Restaurant Administration Quarterly, Vol. 43 No. 3, pp. 87-96.

Gnoth, J. (1997). Tourism motivation and expectation formation. Annals of Tourism Research, 24(2), 283-304.

Gnoth, J., \& Matteucci, X. (2014). A phenomenological view of the behavioural tourism research literature. International Journal of Culture, Tourism and Hospitality Research, 8(1), 3-21.

Gretzel, U., \& Fesenmaier, D. (2010). Capturing sensory experiences through semi-structured elicitation questions. In M. Morgan, P. Lugosi, \& J.R. Ritchie (Eds.), The tourism and leisure experience: Consumer and managerial perspectives (137-160). Bristol, UK: Channel View Publications.

Grewal, D., Levy, M., \& Kumar, V. (2009), Customer experience management in retailing: an organizing framework, Journal of Retailing, 85(1), 1-14.

Gupta, S., \& Vajic, M. (2000). The contextual and dialectical nature of experiences. In J. Fitzsimmons, M.J. Fitzsimmons (Eds.), New service development: Creating Memorable Experiences, (pp. 33-51), Thousand Oaks: Sage Publications.

Ha, J. \& Jang, S.S. (2010), Effects of service quality and food quality: the moderating role of atmospherics in an ethnic restaurant segment, International Journal of Hospitality Management, 29(3), 520-529.

Hayes, J. E. (2015). Measuring sensory perception in relation to consumer behavior. In J. Delarue, J.B. Lawlor, \& M. Rogeaux (Eds.), Rapid sensory profiling techniques (pp. 5369). Sawston, UK: Woodhead Publishing.

Hirschman, E. C. (1984). Experience seeking: a subjectivist perspective of consumption. Journal of Business Research, 12(1), 115-136. 
Holbrook, M. B. (2000). The millennial consumer in the texts of our times: Experience and entertainment. Journal of Macromarketing, 20(2), 178-192.

Holbrook, M. B., \& Hirschman, E. C. (1982). The experiential aspects of consumption: Consumer fantasies, feelings, and fun. Journal of Consumer Research, 9, 132-140.

Hosany, S., Prayag, G., Deesilatham, S., Causevic, S., \& Odeh, K. (2015). Measuring tourists' emotional experiences: Further validation of the destination emotion scale. Journal of Travel Research, 54(4), 482-495.

Hwang, J., \& Lin, T.N. (2010), Effects of food neophobia, familiarity, and nutrition information on consumer acceptance of Asian menu items, Journal of Hospitality Marketing and Management, 19(2), 171-187.

Hwang, J., \& Seo, S. (2016). A critical review of research on customer experience management: Theoretical, methodological and cultural perspectives. International Journal of Contemporary Hospitality Management, 28(10), 2218-2246.

Iglesias, O., Singh, J. J., \& Batista-Foguet, J. M. (2011), The role of brand experience and affective commitment in determining brand loyalty, Journal of Brand Management, $18(8), 570-582$.

Ismail, A. R. (2011), Experience marketing: An empirical investigation, Journal of Relationship Marketing, 10(3), 167-201.

Jennings, G., \& Nickerson, N. (Eds.). (2006). Quality tourism experiences. Burlington, MA: Routledge.

Jones, C. D., Hollenhorst, S. J., \& Perna, F. (2003). An empirical comparison of the four channel flow model and adventure experience paradigm. Leisure Sciences, 25(1), 17-31.

Kahneman, D., \& Tversky, A. (1979). On the interpretation of intuitive probability: A reply to Jonathan Cohen. Cognition, 7(4), 409-411.

Kim, J. H., \& Jang, S. S. (2014). A scenario-based experiment and a field study: A comparative examination for service failure and recovery. International Journal of Hospitality Management, 41, 125-132.

Kim, J., \& Fesenmaier, D. R. (2015). Measuring emotions in real time: Implications for tourism experience design. Journal of Travel Research, 54(4), 419-429.

Kim, J.-H., Ritchie, J. R. B., \& McCormick, B. (2012). Development of a scale to measure memorable tourism experiences. Journal of Travel Research, 51(1), 12-25. 
Kirpalany, N. (2011). Motivation and goal: Goal-theoretic perspectives of consumer suspicion in value co-creation. AMA Summer Educators Conference Proceedings, 22, 224-225.

Klaus, P. P., \& Maklan, S. (2013). Towards a better measure of customer experience. International Journal of Market Research, 55(2), 227-246.

Kreibig, S. D. (2010). Autonomic nervous system activity in emotion: A review. Biological Psychology, 84(3), 394-421.

Kuppelwieser, V. G., \& Finsterwalder, J. (2011). Psychological safety, contributions and service satisfaction of customers in group service experiences. Managing Service Quality: An International Journal, 21(6), 617-635.

Kwun, D. J. W., \& Oh, H. (2007), Past experience and self-image in fine dining intentions, Journal of Foodservice Business Research, 9(4), 3-23.

Laeng, B., Suegami, T., \& Aminihajibashi, S. (2016). Wine labels: an eye-tracking and pupillometry study. International Journal of Wine Business Research, 28(4), 327-348.

Lan Luo, P. K. K., \& Ratchford, B. (2008). Incorporating subjective characteristics in product design and evaluations. Journal of Marketing Research, 45(2), 182-194.

Larsen, R. J., \& Fredrickson, B. L. (1999). Measurement issues in emotion research. In D. Kahneman, E. Diener, \& N. Schwarz (Eds.), Well-being: The foundations of hedonic psychology (pp. 40-60). New York, NY: Russell Sage Foundation.

Larsen, S. (2007). Aspects of a psychology of the tourist experience. Scandinavian Journal of Hospitality and Tourism, 7(1), 7-18.

Lee, W., Gretzel, U., \& Law, R. (2010), Quasi-trial experiences through sensory information on destination web sites, Journal of Travel Research, 49(3), 310-322.

Mak, A. H., Lumbers, M., Eves, A., \& Chang, R.C. (2012), Factors influencing tourist food consumption, International Journal of Hospitality Management, 31(3), 928-936.

Mannell, R. C., \& Kleiber, D. A. (1997). A social psychology of leisure. State College, PA: Venture Publishing.

Mascarenhas, O. A., Kesavan, R., \& Bernacchi, M. (2006). Lasting customer loyalty: a total customer experience approach. Journal of Consumer Marketing, 23(7), 397-405.

Mauss, I. B., \& Robinson, M. D. (2009). Measures of emotion: A review. Cognition and Emotion, 23(2), 209-237. 
Meyer, C., \& Schwager, A. (2007). Customer experience. Harvard Business Review, 85(2), 116126.

Namkung, Y. \& Jang, S. (2007), Does food quality really matter in restaurants? Its impact on customer satisfaction and behavioral intentions, Journal of Hospitality and Tourism Research, 31(30), 387-409.

North, A.C., Shilcock, A., \& Hargreaves, D.J. (2003), The effect of musical style on restaurant customers' spending, Environment and Behavior, 35(5), 712-718.

O’Dell, T., \& Billing, P. (2005). Experiencescapes: Tourism, culture and economy. Frederiksberg: Copenhagen Business School Press.

Oh, H., Fiore, A. M., \& Jeoung, M. (2007). Measuring experience economy concepts: Tourism applications. Journal of Travel Research, 46(2), 119-132.

Ooi, C. (2005). A theory of tourism experiences: The management of attention. In T. O'Dell \& P. Billing (Eds.), Experiencescapes (pp. 51-68). Koge, Denmark: Copenhagen Business School Press.

O'Sullivan, E. L., \& Spangler, K. J. (1998). Experience marketing: Strategies for the new Millennium. State College, PA: Venture Publishing Inc.

Otto, J. E., \& Ritchie, J. B. (1996). The service experience in tourism. Tourism Management, 17(3), 165-174.

Packer, J., \& Ballantyne, R. (2016). Conceptualizing the visitor experience: A review of literature and development of a multifaceted model. Visitor Studies, 19(2), 128-143.

Palmer, A. (2010). Customer experience management: a critical review of an emerging idea. Journal of Services Marketing, 24(3), 196-208.

Parkinson, B., \& Manstead, A. S. R. (1992). Appraisal as a cause of emotion. In M. S. Clark (Ed.), Review of personality and social psychology, No. 13. Emotion (p. 122-149). Thousand Oaks, CA: Sage Publications.

Paulhus, D. L., \& Vazire, S. (2007). The self-report method. Handbook of research methods in personality psychology, 1, 224-239.

Pearce, P. L., \& Caltabiano, M. L. (1983). Inferring travel motivation from travelers' experiences. Journal of Travel Research, 22(2), 16-20.

Pearce, P. L., \& Moscardo, G. M. (1986). The concept of authenticity in tourist experiences. The Australian and New Zealand Journal of Sociology, 22(1), 121-132. 
Pine, B. J. \& Gilmore, J. 1998. Welcome to the experience economy. Harvard Business Review, $78(1), 97-105$.

Pine, B. J., \& Gilmore, J. H. (1999). The Experience Economy: Work Is Theatre \& Every Business a Stage. Boston, MA: Harvard Business School Press.

Pizam, A., \& Tasci, A. D. (2019). Experienscape: expanding the concept of servicescape with a multi-stakeholder and multi-disciplinary approach (invited paper for 'luminaries' special issue of International Journal of Hospitality Management). International Journal of Hospitality Management, 76, 25-37.

Poels, K., \& Dewitte, S. (2006). How to capture the heart? Reviewing 20 years of emotion measurement in advertising. Journal of Advertising Research, 46(1), 18-37.

Poulsson, S. H., \& Kale, S. H. (2004). The experience economy and commercial experiences. Marketing Review, 4(3), 267-277.

Prahalad, C. K., \& Ramaswamy, V. (2004). Co-creation experiences: The next practice in value creation. Journal of Interactive Marketing, 18(3), 5-14.

Prayag, G., Hosany, S., Muskat, B., \& Del Chiappa, G. (2017). Understanding the relationships between tourists' emotional experiences, perceived overall image, satisfaction, and intention to recommend. Journal of Travel Research, 56(1), 41-54.

Quinlan Cutler, S., Doherty, S., \& Carmichael, B. (2018). The experience sampling method: examining its use and potential in tourist experience research. Current Issues in Tourism, 21(9), 1052-1074.

Rahmani, K., Gnoth, J., \& Mather, D. (2019). A Psycholinguistic View of Tourists’ Emotional Experiences. Journal of Travel Research, 58(2), 192-206.

Rose, S., Clark, M., Samouel, P., \& Hair, N. (2012). Online customer experience in e-retailing: an empirical model of antecedents and outcomes. Journal of Retailing, 88(2), 308-322.

Ross, M. (1989). Relation of implicit theories to the construction of personal histories. Psychological Review, 96(2), 341-357.

Roth, A. V., \& Menor, L. J. (2003). Insights into service operations management: A research agenda. Production and Operations Management, 12(2), 145-164.

Russell, J. A., \& Mehrabian, A. (1977). Evidence for a three-factor theory of emotions. Journal of research in Personality, 11(3), 273-294. 
Rust, R. T., Zeithaml, V. A., \& Lemon, K. N. (2001). Driving customer equity: How customer lifetime value is reshaping corporate strategy (1 st ed.). New York, NY: Free Press.

Sacco, T., \& Sacchetti, B. (2010). Role of secondary sensory cortices in emotional memory storage and retrieval in rats. Science, 329(5992), 649-656.

San Martin, H., Collado, J., \& Rodriguez del Bosque, I. (2013). An exploration of the effects of past experience and tourist involvement on destination loyalty formation. Current Issues in Tourism, 16(4), 327-342.

Schmitt, B. (1999). Experiential marketing. Journal of Marketing Management, 15(1-3), 53-67.

Selstad, L. (2007). The social anthropology of the tourist experience. Exploring the "middle role”. Scandinavian Journal of Hospitality and Tourism, 7(1), 19-33.

Shaw, C., \& Ivens, J. (2002). Building great customer experiences. London, GB: Palgrave.

Soodan, V., \& Pandey, A. C. (2016). Influence of emotions on consumer buying behavior. Journal of Entrepreneurship, Business and Economics, 4(2), 163-181.

Stern, R. M., Ray, W. J., \& Quigley, K. S. (2001). Psychophysiological recording. New York, NY: Oxford University Press.

Terblanche, N. S., \& Boshoff, C. (2001). Measuring customer satisfaction with some of the controllable elements of the total retail experience: an exploratory study. South African Journal of Business Management, 32(2), 35-42.

Tsaur, S. H., Chiu, Y. T., \& Wang, C. H. (2007). The visitors behavioral consequences of experiential marketing: An empirical study on Taipei Zoo. Journal of Travel \& Tourism Marketing, 21(1), 47-64.

Tse, P., \& Crotts, J.C. (2005), Antecedents of novelty seeking: international visitors' propensity to experiment across Hong Kong's culinary traditions, Tourism Management, 26(6), 965 968.

Tynan, C., \& McKechnie, S. (2009). Experience marketing: a review and reassessment. Journal of Marketing Management, 25(5-6), 501-517.

Unger, L., \& Kernan, J. (1983). On the meaning of leisure: An investigation of some determinants of the subjective experience. Journal of Consumer Research, 9(4), 381-392.

Verhoef, P. C., Lemon, K. N., Parasuraman, A., Roggeveen, A., Tsiros, M., \& Schlesinger, L. A. (2009). Customer experience creation: Determinants, dynamics and management strategies. Journal of Retailing, 85(1), 31-41. 
Volo, S. (2009). Conceptualizing experience: A tourist based approach. Journal of Hospitality Marketing \& Management, 18(2/3), 111-126.

Vuilleumier, P. (2005). How brains beware: neural mechanisms of emotional attention. Trends in cognitive sciences, 9(12), 585-594.

Wang, N. (1999). Rethinking authenticity in tourism experience. Annals of Tourism Research, 26(2), 349-370.

Wendin, K., Allesen-Holm, B. H., \& Bredie, W. L. (2011). Do facial reactions add new dimensions to measuring sensory responses to basic tastes?. Food Quality and Preference, 22(4), 346-354.

Wijaya, S., King, B., Nguyen, T.H. \& Morrison, A. (2013), International visitor dining experiences: a conceptual framework, Journal of Hospitality and Tourism Management, $20,34-42$.

Wilhelm, F. H., \& Grossman, P. (2010). Emotions beyond the laboratory: Theoretical fundaments, study design, and analytic strategies for advanced ambulatory assessment. Biological Psychology, 84(3), 552-569.

Williams, A. (2006), Tourism and hospitality marketing: fantasy, feeling and fun, International Journal of Contemporary Hospitality Management, 18(6), 482-495.

Yi, Y., \& Gong, T. (2009). An integrated model of customer social exchange relationship: The moderating role of customer experience. The Service Industries Journal, 29(11), 15131528. 